Article

\title{
Influence of Oxygen Contents on the Microstructure, High Temperature Oxidation and Corrosion Resistance Properties of $\mathrm{Cr}-\mathrm{Si}-\mathrm{O}-\mathrm{N}$ Coatings
}

\author{
Jinjue Liang ${ }^{1,2}$, Shimin Chen ${ }^{2}$, Changwei Zou ${ }^{2, *}$, Canxin Tian ${ }^{2}$, Zesong Wang ${ }^{2}$ and \\ Shijun Liao ${ }^{1}$ \\ 1 School of Chemistry and Chemical Engineering, South China University of Technology, \\ Guangzhou 510640, China; liangjinjue@126.com (J.L.); chsjliao@scut.edu.cn (S.L.) \\ 2 School of Physics Science and Technology, Lingnan Normal University, Zhanjiang 524048, China; \\ shiminchen520@163.com (S.C.); cxtian@whu.edu.cn (C.T.); zswang531@163.com (Z.W.) \\ * Correspondence: qingyihaiyanas@163.com; Tel.: +86-75-9318-3260
}

Received: 8 November 2017; Accepted: 25 December 2017; Published: 3 January 2018

\begin{abstract}
Cr}-\mathrm{Si}-\mathrm{O}-\mathrm{N}$ coatings with different oxygen contents were deposited by multi-arc ion plating, where various $\mathrm{O}_{2} /\left(\mathrm{N}_{2}+\mathrm{O}_{2}\right)$ reactive gas rates were adopted. The XRD and XPS results showed that the $\mathrm{CrN}$ crystals disappeared with the increasing of the oxygen flux ratio to 10 at.\%. The microhardness of all the $\mathrm{Cr}-\mathrm{Si}-\mathrm{O}-\mathrm{N}$ coatings was approximately $2000 \mathrm{Hv}_{0.05}$, which were dramatically plummeted compared to that of the $\mathrm{Cr}-\mathrm{Si}-\mathrm{N}$ coatings $\left(\approx 3300 \mathrm{Hv}_{0.05}\right)$. The $\mathrm{Cr}-\mathrm{Si}-\mathrm{O}-\mathrm{N}$ coatings were annealed under $800{ }^{\circ} \mathrm{C}$ and $1200{ }^{\circ} \mathrm{C}$ in the air atmosphere for $2 \mathrm{~h}$ to study the high-temperature oxidation resistance of the coatings. Meanwhile, $\mathrm{Cr}-\mathrm{Si}-\mathrm{O}-\mathrm{N}$ coatings with different $\mathrm{O}_{2} /\left(\mathrm{N}_{2}+\mathrm{O}_{2}\right)$ rates were also used to carry out the corrosion resistance testing using the electrochemical working station in $3.5 \% \mathrm{NaCl}$ solution under free air condition at room temperature. The results indicated that the coatings containing oxygen were more vulnerable to the high-temperature destruction and more easily corroded in the $\mathrm{NaCl}$ electrolyte.
\end{abstract}

Keywords: $\mathrm{Cr}-\mathrm{Si}-\mathrm{O}-\mathrm{N}$; oxygen contents; microhardness; high-temperature oxidation resistance; corrosion resistance

\section{Introduction}

$\mathrm{CrN}$ has been one of the most extensively used hard coatings for various forming and casting applications [1,2], due to its excellent high-temperature oxidation resistance and good corrosion resistance [3,4]. In recent years, efforts have been continuously devoted in order to further improve the properties of $\mathrm{CrN}$ coatings. One of the most promising approaches is to synthesize the $\mathrm{Cr}-\mathrm{Si}-\mathrm{N}$ nanocomposite coatings, which follows the design concept of superhard nc-MeN/a-Si $\mathrm{N}_{4}$ proposed by Veprek et al. [5].

In the nanocomposites coatings, the oxygen has a great impact on the properties. On one hand, it has been reported that the oxygen impurity could be critically harmful to the superhard nanocomposite coatings [6,7]. Veprek et al. [8] synthesized the Ti-Si-N superhard nanocomposites coatings with a hardness of $\geq 50 \mathrm{GPa}$, which was difficult for some other groups to achieve [9-11]. Verprek et al. [8] figured that one of the important reasons for the lack of reproducibility was the oxygen impurity incorporated into the coatings during the deposition process. It was impossible to achieve the hardness of $40 \mathrm{GPa}$ when the oxygen impurity was larger than 0.4 at.\%. Ma et al. [12] also reported that oxygen impurity of 1-1.5 at.\% could lead to a sharp decrease in hardness to $30 \mathrm{GPa}$, while they could obtain $45-55 \mathrm{GPa}$ in the nc-TiN/a-Si $\mathrm{N}_{4}$ coatings by controlling the oxygen impurity below 0.2 at.\%. On the other hand, however, Lee et al. [13] reported that the mechanical and tribological 
properties of the $\mathrm{Cr}-\mathrm{Si}-\mathrm{O}-\mathrm{N}$ nanocomposite coatings with appropriate oxygen contents were much better than that of the $\mathrm{Cr}-\mathrm{Si}-\mathrm{N}$ coatings. Therefore, it is really important to investigate the influence of the oxygen and the oxygen contents on the properties of $\mathrm{Cr}-\mathrm{Si}-\mathrm{N}$ coatings.

In this work, the quaternary $\mathrm{Cr}-\mathrm{Si}-\mathrm{O}-\mathrm{N}$ coatings with different oxygen contents were deposited by a multi-arc ion plating process in a $\mathrm{N}_{2}+\mathrm{O}_{2}$ atmosphere. The microstructure, mechanical, high-temperature oxidation and electrochemical corrosion resistance properties of the $\mathrm{Cr}-\mathrm{Si}-\mathrm{O}-\mathrm{N}$ coatings, as a function of oxygen contents, were systematically investigated. Although scant information about the deposition of the $\mathrm{Cr}-\mathrm{Si}-\mathrm{O}-\mathrm{N}$ coatings has been reported [14], the influence of varying the oxygen content to the microstructure and properties of the $\mathrm{Cr}-\mathrm{Si}-\mathrm{O}-\mathrm{N}$ coatings is still relatively unclear.

\section{Experimental Details}

Cr-Si-O-N coatings were deposited by the multi-arc ion plating technique (supplied by company of DongGuan HuiCheng Mechanical Engineering, Dongguan, China) under a deposition temperature of approximately $100{ }^{\circ} \mathrm{C}$, where the $\mathrm{CrSi}$ target (Cr 85 at.\% and $\mathrm{Si} 15$ at.\%, cylindrical in shape and with a diameter of $95 \mathrm{~mm}$ ) was used as the cathode. During all experiments, the $\mathrm{Cr}-\mathrm{Si}-\mathrm{O}-\mathrm{N}$ coatings with different oxygen contents were obtained by varying the $\mathrm{O}_{2} /\left(\mathrm{N}_{2}+\mathrm{O}_{2}\right)$ flow rate ratio. In this work, the working pressure was stabilized at $1 \mathrm{~Pa}$, and the reactive gas flow rate ratio $\left(\mathrm{O}_{2}\right.$ flow: $\mathrm{N}_{2}$ flow $)$ was set at $0 \%\left(\mathrm{O}_{2}: \mathrm{N}_{2}=0 \mathrm{sccm}: 45 \mathrm{sccm}\right), 2 \%\left(\mathrm{O}_{2}: \mathrm{N}_{2}=0.9 \mathrm{sccm}: 44.1 \mathrm{sccm}\right), 5 \%\left(\mathrm{O}_{2}: \mathrm{N}_{2}=2.25 \mathrm{sccm}: 42.75 \mathrm{sccm}\right), 10 \%$ $\left(\mathrm{O}_{2}: \mathrm{N}_{2}=4.5 \mathrm{sccm}: 40.5 \mathrm{sccm}\right), 15 \%\left(\mathrm{O}_{2}: \mathrm{N}_{2}=6.75 \mathrm{sccm}: 38.25 \mathrm{sccm}\right)$ and $20 \%\left(\mathrm{O}_{2}: \mathrm{N}_{2}=9 \mathrm{sccm}: 36 \mathrm{sccm}\right)$, respectively. Prior to deposition, the WC-Co cemented carbide (16 $\mathrm{mm}$ in diameter, $5 \mathrm{~mm}$ in thickness) and silicon wafer (111) (10 $\mathrm{mm}$ in diameter, $1 \mathrm{~mm}$ in thickness) substrates were ultrasonically cleaned by acetone and alcohol in sequence for $20 \mathrm{~min}$, followed by a rapid Ar drying. Then, the substrates were placed on the sample holder in the middle of the vacuum chamber for the following deposition, and the whole chamber was heated at $300{ }^{\circ} \mathrm{C}$ for $0.5 \mathrm{~h}$. The substrates were DC (direction current) biased at $-100 \mathrm{~V}$ and the current of the $\mathrm{CrSi}$ target was fixed at $70 \mathrm{~A}$. The deposition was performed for 50 min to obtain the $\mathrm{Cr}-\mathrm{Si}-\mathrm{O}-\mathrm{N}$ coatings, whose thickness was about $1.5 \mu \mathrm{m}$ under a working pressure of 1.0 Pa. The parameters of the deposition are summarized in Table 1.

Table 1. The parameters for the deposition of $\mathrm{Cr}-\mathrm{Si}-\mathrm{O}-\mathrm{N}$ coatings.

\begin{tabular}{cccc}
\hline Deposition Parameters & Cr Adhesive Layer & CrN Inter Layer & Cr-Si-O-N \\
\hline Ar flow rates $(\mathrm{sccm})$ & 9 & - & - \\
$\mathrm{N}_{2}$ flow rates $(\mathrm{sccm})$ & - & 60 & 45 \\
$\mathrm{O}_{2} /\left(\mathrm{N}_{2}+\mathrm{O}_{2}\right)$ ratio & - & - & $0-20 \%$ \\
Working pressure (Pa) & 1.0 & 1.0 & 1.0 \\
Deposition time (s) & 300 & 300 & 3000 \\
Cr cathode arc current (A) & 80 & 80 & - \\
CrSi cathode arc current (A) & - & - & 70 \\
Negative bias voltage (V) & -160 & -140 & -100 \\
\hline
\end{tabular}

The coatings deposited on Si wafer were used for oxidation experiment, and the high-temperature oxidation resistance ability was evaluated by comparison of the change of coatings phase using XRD (X-ray diffraction, X'Pert-MPD System, PHILIPS, Amsterdam, The Netherlands) and observation of separation extent between $\mathrm{Cr}-\mathrm{Si}-\mathrm{O}-\mathrm{N}$ coatings and substrates using SEM (scanning electron microscope, MERLIN, ZEISS, Jena, Germany). The experiments were carried out at a heating rate of $10^{\circ} \mathrm{C} / \mathrm{min}$ and the coatings were annealed at $800^{\circ} \mathrm{C}$ and $1200^{\circ} \mathrm{C}$ in the air for $2 \mathrm{~h}$. The electrochemical corrosion test resistance of the deposited $\mathrm{Cr}-\mathrm{Si}-\mathrm{O}-\mathrm{N}$ coatings and WC-Co cemented carbide substrate were tested by an electrochemical working station (CS350, Wuhan Kesite Instrument Co., Ltd., Wuhan, China) in $3.5 \% \mathrm{NaCl}$ solution. The crevice corrosion was carried out under free air condition at room temperature, with scanning range from -0.5 to $1.5 \mathrm{~V}$ versus open circuit potential, and the 
mercury/mercury chloride combined with luggin probe as the reference electrode, and the platinum electrode $\left(1 \mathrm{~cm}^{2}\right)$ as the counter electrode. To obtain accurate curve, Lujin capillary was as close as possible to the study electrode for decreasing liquid potential and the scan rate of $0.5 \mathrm{mV} / \mathrm{s}$ was used. The corrosion potential, corrosion current and polarization resistance obtained from the Tafel plots were used to evaluate the corrosion rate of deposited coatings. In addition, Electrochemical Impedance Spectroscopy (EIS, CS350, Wuhan Kesite Instrument Co., Ltd., Wuhan, China) measurements were recorded at open circuit potential in the frequency range of $10^{-2}-10^{-5} \mathrm{~Hz}$ with a signal amplitude of $10 \mathrm{mV}$ in $3.5 \% \mathrm{NaCl}$ solution. The experiment of Potentiodynamic Polarization Curves, Electrochemical Impedance Spectroscopy and high-temperature oxidation test were repeated for 3 times.

The structure and phases of the $\mathrm{Cr}-\mathrm{Si}-\mathrm{O}-\mathrm{N}$ coatings deposited on $\mathrm{Si}$ wafer were analyzed by X-ray diffraction (XRD, X'Pert-MPD System, PHILIPS, Amsterdam, The Netherlands) with $0.04^{\circ}$ using $\mathrm{Cu} \mathrm{K} \alpha$ radiation. The bonding status of $\mathrm{Cr}-\mathrm{Si}-\mathrm{O}-\mathrm{N}$ coatings was studied by $\mathrm{X}$-ray photoelectron spectra (XPS, PHI X-tool, ULVAC-PHI, Inc., Chigasaki, Japan) with Al K $\alpha$ X-ray at $15 \mathrm{kV}$ and $50 \mathrm{~W}$. The chemical compositions of coatings were investigated by the electron probe microanalyzer (EPMA, EPMA 1600, Shimadzu, Kyoto, Japan). The field emission scanning electron microscope was used to obtain the surface morphology and the cross sectional images of the coatings before and after annealing. The microhardness of $\mathrm{Cr}-\mathrm{Si}-\mathrm{O}-\mathrm{N}$ coatings deposited on cemented carbide substrate were measured by using an HX-1000 micro-hardness tester (ShangHai TaiMing Optical Instrument Co., Ltd., Shanghai, China) with a load of $50 \mathrm{gf}(0.49 \mathrm{~N})$ and the final values are taken from average values of 10 measurements.

\section{Results and Discussion}

\subsection{Composition and Microstructure}

Figure 1 shows the chemical composition of the $\mathrm{Cr}-\mathrm{Si}-\mathrm{O}-\mathrm{N}$ coatings with different flux rates of $\mathrm{O}_{2} /\left(\mathrm{N}_{2}+\mathrm{O}_{2}\right)$. Since the current of the $\mathrm{CrSi}$ target was fixed at $70 \mathrm{~A}$ during all of the deposition processes, the $\mathrm{Cr}$ and $\mathrm{Si}$ contents of the as-deposited coatings were almost constant, being about 51 at.\% and 9 at. \%, respectively. The oxygen contents of the deposited coatings significantly increased from 0 to 40 at. $\%$ and the $\mathrm{N}$ contents sharply decreased from 31.5 at. $\%$ to 5 at. $\%$ when the $\mathrm{O}_{2} /\left(\mathrm{N}_{2}+\mathrm{O}_{2}\right)$ flux rate increased from $0 \%$ to $10 \%$. The Gibbs free energy of $\mathrm{Cr}-\mathrm{O}$ is lower than that of $\mathrm{Cr}-\mathrm{N}$ [15], so the residual oxygen is more likely to remain in the coatings in the form of $\mathrm{Cr}_{x} \mathrm{O}_{y}$. However, both the $\mathrm{O}$ and $\mathrm{N}$ contents remained the same with the further increase of the $\mathrm{O}_{2} /\left(\mathrm{N}_{2}+\mathrm{O}_{2}\right)$ flux rate, which might result from the saturation of the $\mathrm{O}_{2}$ in the chamber.

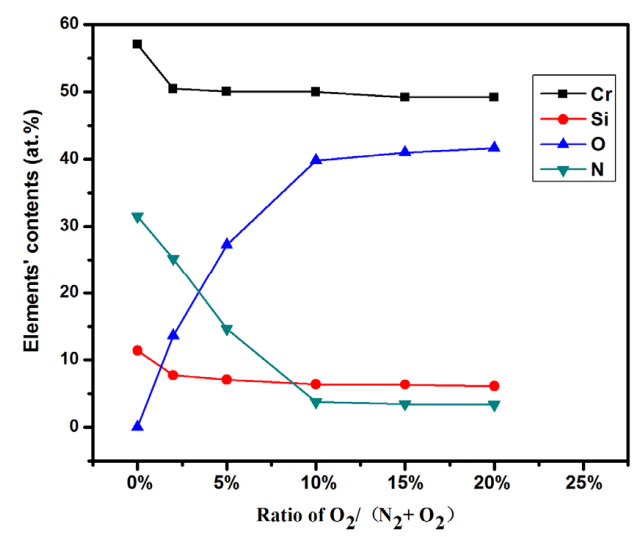

Figure 1. Chemical composition (obtained by EPMA) of $\mathrm{Cr}-\mathrm{Si}-\mathrm{O}-\mathrm{N}$ coatings as a function of $\mathrm{O}_{2} /\left(\mathrm{N}_{2}+\mathrm{O}_{2}\right)$ flux rate.

Figure 2 shows the XRD spectra of $\mathrm{Cr}-\mathrm{Si}-\mathrm{O}-\mathrm{N}$ coatings as a function of $\mathrm{O}_{2} /\left(\mathrm{N}_{2}+\mathrm{O}_{2}\right)$ flux rate. It can be seen that only the diffraction peaks of $\mathrm{CrN}$ (111) and $\mathrm{CrN}$ (200) were detected for the 
$\mathrm{Cr}-\mathrm{Si}-\mathrm{N}$ coatings. However, with the addition of oxygen, the diffraction peaks became weaker and the diffraction peaks of crystalline phase were no longer recognizable when the $\mathrm{O}_{2} /\left(\mathrm{N}_{2}+\mathrm{O}_{2}\right)$ flux rate above $10 \%$. The more oxygen in the chamber, the more $\mathrm{Cr}$ from the $\mathrm{CrN}$ was despoiled to form the $\mathrm{Cr}_{x} \mathrm{O}_{y}$. Unlike the results from other researchers [13], the formed $\mathrm{Cr}_{x} \mathrm{O}_{y}$ in our as-deposited coatings existed in the amorphous phase, which is because the deposition temperature in our system is not high enough to form the crystalline phase. In addition, no crystalline peaks of $\mathrm{Si}_{3} \mathrm{~N}_{4}$ and $\mathrm{SiO}_{2}$ were detected in the XRD spectra, which can also be attributed to the low temperature deposition process.

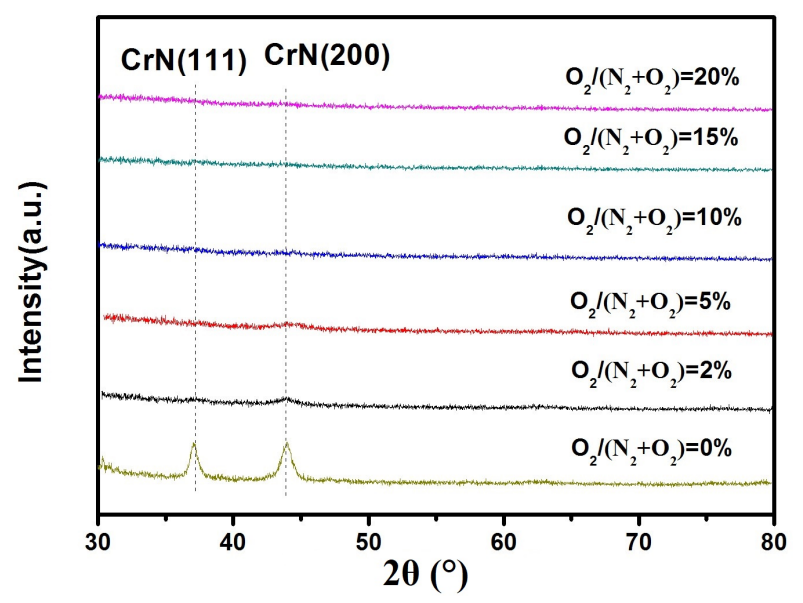

Figure 2. The XRD spectra of $\mathrm{Cr}-\mathrm{Si}-\mathrm{O}-\mathrm{N}$ coatings as a function of $\mathrm{O}_{2} /\left(\mathrm{N}_{2}+\mathrm{O}_{2}\right)$ flux rate.

Figure 3 presents the $\mathrm{Si} 2 p$ and $\mathrm{N}$ 1s spectra of $\mathrm{Cr}-\mathrm{Si}-\mathrm{O}-\mathrm{N}$ coatings deposited under the $\mathrm{O}_{2} /\left(\mathrm{N}_{2}+\mathrm{O}_{2}\right)$ flux rate of $2 \%$ and $20 \%$. The binding energy of $\mathrm{Si}$ for both coatings appeared at $101.5 \mathrm{eV}$ (Figure 3a), which is in good agreement with that of $\mathrm{Si}_{3} \mathrm{~N}_{4}$ phase [14]. In addition, little peaks of $\mathrm{SiO}_{2}$ phase appeared at $102.9 \mathrm{eV}$ [13]. In the $\mathrm{N} 1 \mathrm{~s}$ spectra, we can find peaks at 396.7 and $397.9 \mathrm{eV}$, which correspond to $\mathrm{CrN} \mathrm{[16]} \mathrm{and} \mathrm{Si}_{3} \mathrm{~N}_{4}$ [17], respectively, in the coating with lower $\mathrm{O}_{2} /\left(\mathrm{N}_{2}+\mathrm{O}_{2}\right)$ flux rate. However, when the flux rate increased to $20 \%$, the peak corresponding to $\mathrm{CrN}$ disappeared, indicating that there was no crystalline $\mathrm{CrN}$ phase existing in the coatings anymore, and the left $\mathrm{N}$ in the coatings was all in the amorphous form of $\mathrm{Si}_{3} \mathrm{~N}_{4}$. This also implied that crystal phase of $\mathrm{CrN}$ was present at lower $\mathrm{O}_{2} /\left(\mathrm{N}_{2}+\mathrm{O}_{2}\right)$ flux rate in accordance with XRD results.
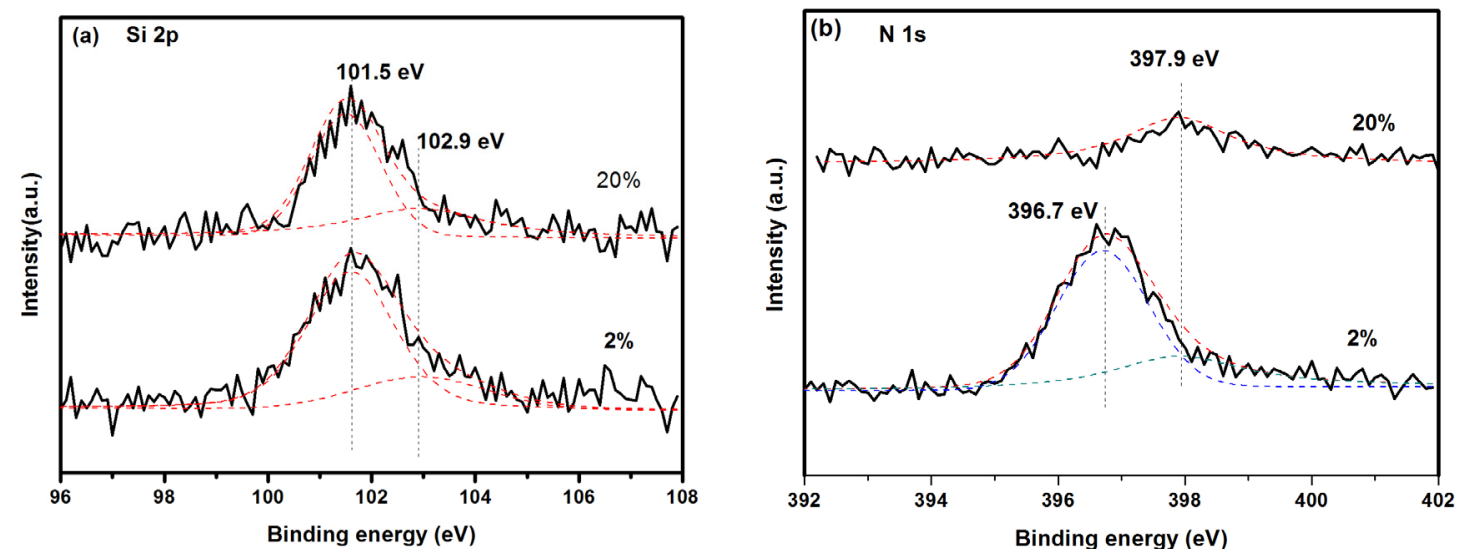

Figure 3. The XPS spectra of $\mathrm{Cr}-\mathrm{Si}-\mathrm{O}-\mathrm{N}$ coatings deposited under the $\mathrm{O}_{2} /\left(\mathrm{N}_{2}+\mathrm{O}_{2}\right)$ flux rate of $2 \%$ and $20 \%$ : (a) Si $2 p$; (b) N 1 s. 
The surface and cross-sections SEM images of $\mathrm{Cr}-\mathrm{Si}-\mathrm{O}-\mathrm{N}$ coatings deposited under different $\mathrm{O}_{2} /\left(\mathrm{N}_{2}+\mathrm{O}_{2}\right)$ flux rates are shown in Figure 4. Many micro-particles can be seen on the surface of both coatings, which were introduced by the multi-arc ion plating during experiments [18].
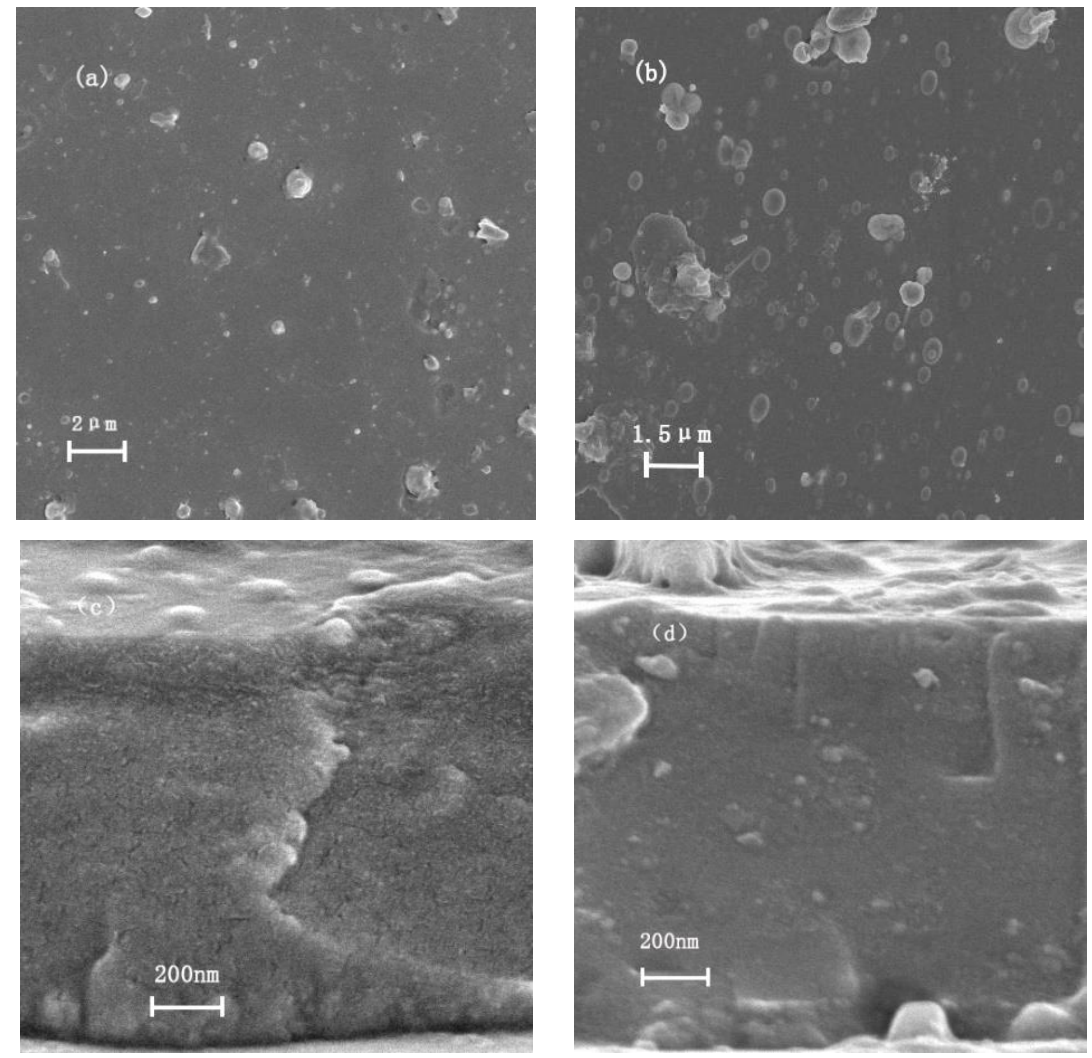

Figure 4. The surface and cross-section SEM images of $\mathrm{Cr}-\mathrm{Si}-\mathrm{O}-\mathrm{N}$ coatings deposited as a function of $\mathrm{O}_{2} /\left(\mathrm{N}_{2}+\mathrm{O}_{2}\right)$ flux rate: (a,b) surface images, $\mathrm{O}_{2} /\left(\mathrm{N}_{2}+\mathrm{O}_{2}\right)=2 \%$; $(\mathbf{c}, \mathbf{d})$ cross-section images, $\mathrm{O}_{2} /\left(\mathrm{N}_{2}+\mathrm{O}_{2}\right)=10 \%$.

\subsection{Microhardness, High Temperature Test and Corrosion Test}

Figure 5 shows the hardness value of $\mathrm{Cr}-\mathrm{Si}-\mathrm{O}-\mathrm{N}$ coating as a function of $\mathrm{O}_{2} /\left(\mathrm{N}_{2}+\mathrm{O}_{2}\right)$ flux rate. It can be found clearly that the hardness sharply decreased with the addition of the oxygen from 0 to 2 at. $\%$ and slightly decreased with the further increase of the oxygen above 5 at. $\%$. The hardness value of cemented carbide substrate is about $1260 \mathrm{Hv}_{0.05}$, and the hardness of all the $\mathrm{Cr}-\mathrm{Si}-\mathrm{O}-\mathrm{N}$ coatings is ranging around $2000 \mathrm{Hv}_{0.05}$ which is far less than the $\mathrm{Cr}-\mathrm{Si}-\mathrm{N}$ coatings. This phenomenon might be attributed to the formation of a large proportion of the $\mathrm{Cr}_{x} \mathrm{O}_{y}$ amorphous phase in the as-deposited coatings which disrupted the formation of the nanocomposite structure of amorphous matrix and crystalline [19].

The $\mathrm{Cr}-\mathrm{Si}-\mathrm{O}-\mathrm{N}$ coatings deposited under $\mathrm{O}_{2} /\left(\mathrm{N}_{2}+\mathrm{O}_{2}\right)$ flux rate of $2 \%$ and $10 \%$ were chosen to do the high-temperature oxidation treatments. The XRD spectra of the coatings before and after oxidation under $800^{\circ} \mathrm{C}$ and $1200^{\circ} \mathrm{C}$ in the air were shown in Figure 6 . After the coatings were annealed under $800{ }^{\circ} \mathrm{C}$ in the air for $2 \mathrm{~h}$, some diffraction patterns of $\mathrm{Cr}_{2} \mathrm{O}_{3}$ and $\mathrm{CrO}_{2}$ were detected in both coatings, which suggested that small extent of oxidation behavior might occur on the surface. The number of oxide diffraction patterns in the coatings with lower oxygen was much less than that in the higher one, indicating that the high-temperature oxidation ability of the former might be better. As the oxidation temperature rose to $1200{ }^{\circ} \mathrm{C}$, the diffraction peaks, corresponding to $\mathrm{Cr}_{2} \mathrm{O}_{3}$ and $\mathrm{CrO}_{2}$, became stronger, and their number increased, indicating that the oxidation progressed. The crystalline $\mathrm{Cr}_{2} \mathrm{O}_{3}$ and $\mathrm{CrO}_{2}$ appear due to oxidation of the coatings and crystallisation of amorphous 
$\mathrm{Cr}_{x} \mathrm{O}_{y}$ phase during annealing. Owing to $\mathrm{SiO}_{2}$ presents in terms of amorphous [20], it was noted that no diffraction pattern of $\mathrm{SiO}_{2}$ was detected in all the XRD spectra. Meanwhile, Kim et al. proposed that the crystal $\mathrm{CrN}$ phase of $\mathrm{Cr}-\mathrm{Si}-\mathrm{N}$ coatings did not disappear thoroughly and maintained good oxidation resistance even the annealing temperature up to $1000^{\circ} \mathrm{C}$ [21], which implied that $\mathrm{CrN}$ phase included in the coatings was reasonable, as shown in Figure $6 \mathrm{a}$.

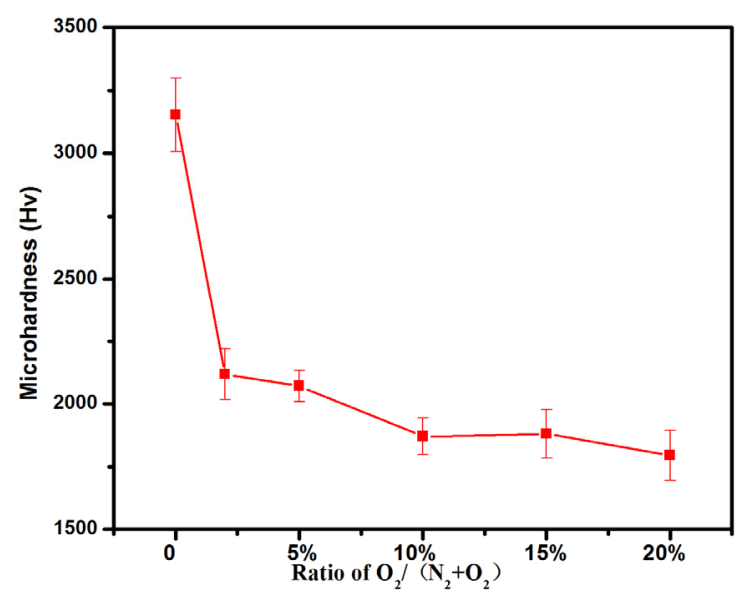

Figure 5. The microhardness values of $\mathrm{Cr}-\mathrm{Si}-\mathrm{O}-\mathrm{N}$ coating as a function of $\mathrm{O}_{2} /\left(\mathrm{N}_{2}+\mathrm{O}_{2}\right)$ flux rate.
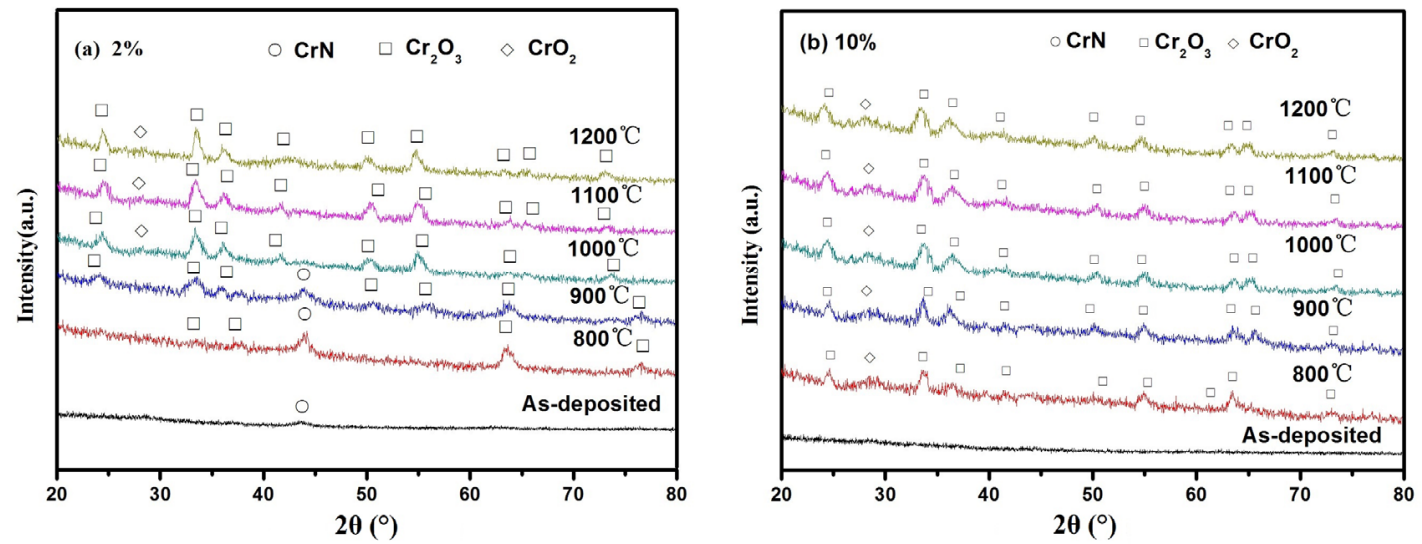

Figure 6. The XRD spectra of $\mathrm{Cr}-\mathrm{Si}-\mathrm{O}-\mathrm{N}$ coatings deposited under various oxygen contents before and after annealing from 800 to $1200{ }^{\circ} \mathrm{C}$ in the air for $2 \mathrm{~h}$ : (a) $\mathrm{O}_{2} /\left(\mathrm{N}_{2}+\mathrm{O}_{2}\right)=2 \%$; (b) $\mathrm{O}_{2} /\left(\mathrm{N}_{2}+\mathrm{O}_{2}\right)=10 \%$.

The SEM images of the coatings after oxidation are illustrated in Figure 7. There are some chromium oxide crystallites (confirmed by EDS test) covering the surface of the coatings and those oxide crystallites may derive from the outward diffusion of the chromium. The higher the temperature is, the more oxide crystallites there are. The cross-sectional images in Figure 8 show that both of the coatings deposited under $\mathrm{O}_{2} /\left(\mathrm{N}_{2}+\mathrm{O}_{2}\right)$ flux rate of $2 \%$ and $10 \%$ keep intact after the $800{ }^{\circ} \mathrm{C}$ oxidation. However, after the higher temperature oxidation, the destruction occurred. It can be observed clearly that the extent of oxidation destruction are severer in the coatings with higher oxygen content and the coatings tend to be peel off from the substrate. The strong detriment of the high-temperature oxidation resistance of the as-deposited coatings may attribute to the lack of the nanocomposite structure $[10,22,23]$. Figure 8 shows the SEM images and EDS spectra of $\mathrm{Cr}-\mathrm{Si}-\mathrm{O}-\mathrm{N}$ coatings with the oxygen flow ratio of $2 \%$ and $10 \%$ after annealing. Although a large nubmer of fluffy macroparticles that were chromium oxide detected by EDS spectra were present on the surface of the samples, Figure $8 \mathrm{c}, \mathrm{f}$ still showed that the coatings have not been damaged completely. Figure $8 \mathrm{f}$ also confirmed that the concentration of $\mathrm{Si}$ was not large. In other words, the coatings can resist to destruction at $1100{ }^{\circ} \mathrm{C}$. 
The cross-sectional chemical compositions of the coatings deposited under both the oxygen contents after annealing at 800,1100 and $1200^{\circ} \mathrm{C}$ have been recited in Table 2 . It was obvious that the $\mathrm{Cr}$ contents reduced, $\mathrm{Si}$ and $\mathrm{O}$ contents increased when annealing temperature ranged from 800 to $1200{ }^{\circ} \mathrm{C}$, and $\mathrm{N}$ contents calculated by subtracting the sum of $\mathrm{Cr}, \mathrm{Si}$ and $\mathrm{O}$ contents from $100 \%$ had a decreasing trendency. This revealed that the $\mathrm{CrN}$ phase degraded as the annealing temperature rose, which can be in agreement with XRD results.
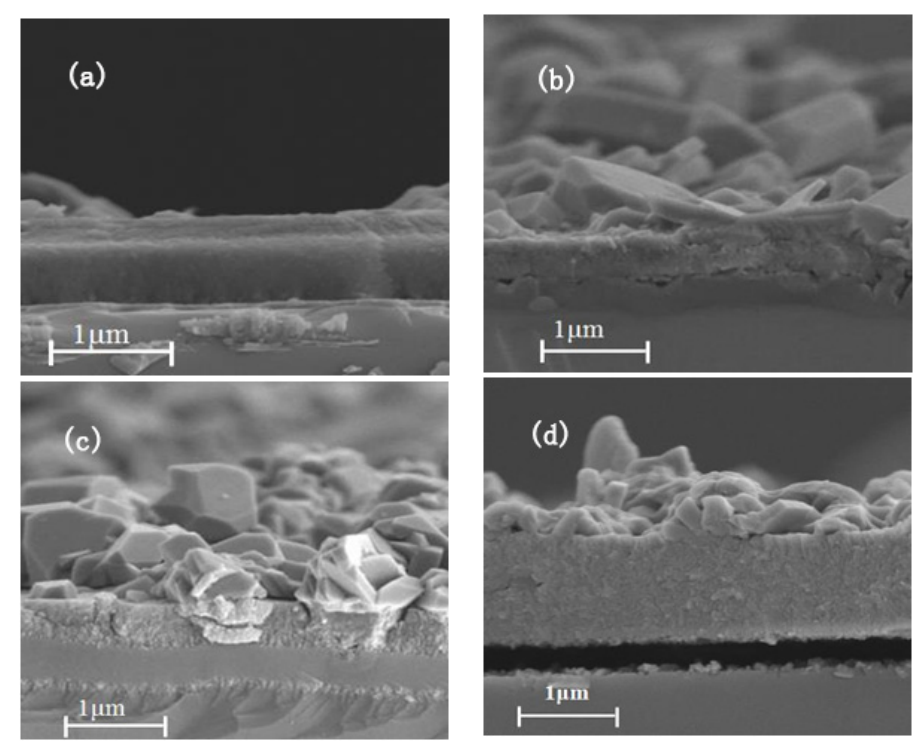

Figure 7. The cross-sectional images of $\mathrm{Cr}-\mathrm{Si}-\mathrm{O}-\mathrm{N}$ coatings after annealing in the air for $2 \mathrm{~h}$ : (a) $\mathrm{O}_{2} /\left(\mathrm{N}_{2}+\mathrm{O}_{2}\right)=2 \%, 800{ }^{\circ} \mathrm{C}$; (b) $\mathrm{O}_{2} /\left(\mathrm{N}_{2}+\mathrm{O}_{2}\right)=2 \%, 1200{ }^{\circ} \mathrm{C}$; (c) $\mathrm{O}_{2} /\left(\mathrm{N}_{2}+\mathrm{O}_{2}\right)=10 \%, 800{ }^{\circ} \mathrm{C}$; (d) $\mathrm{O}_{2} /\left(\mathrm{N}_{2}+\mathrm{O}_{2}\right)=10 \%, 1200^{\circ} \mathrm{C}$.
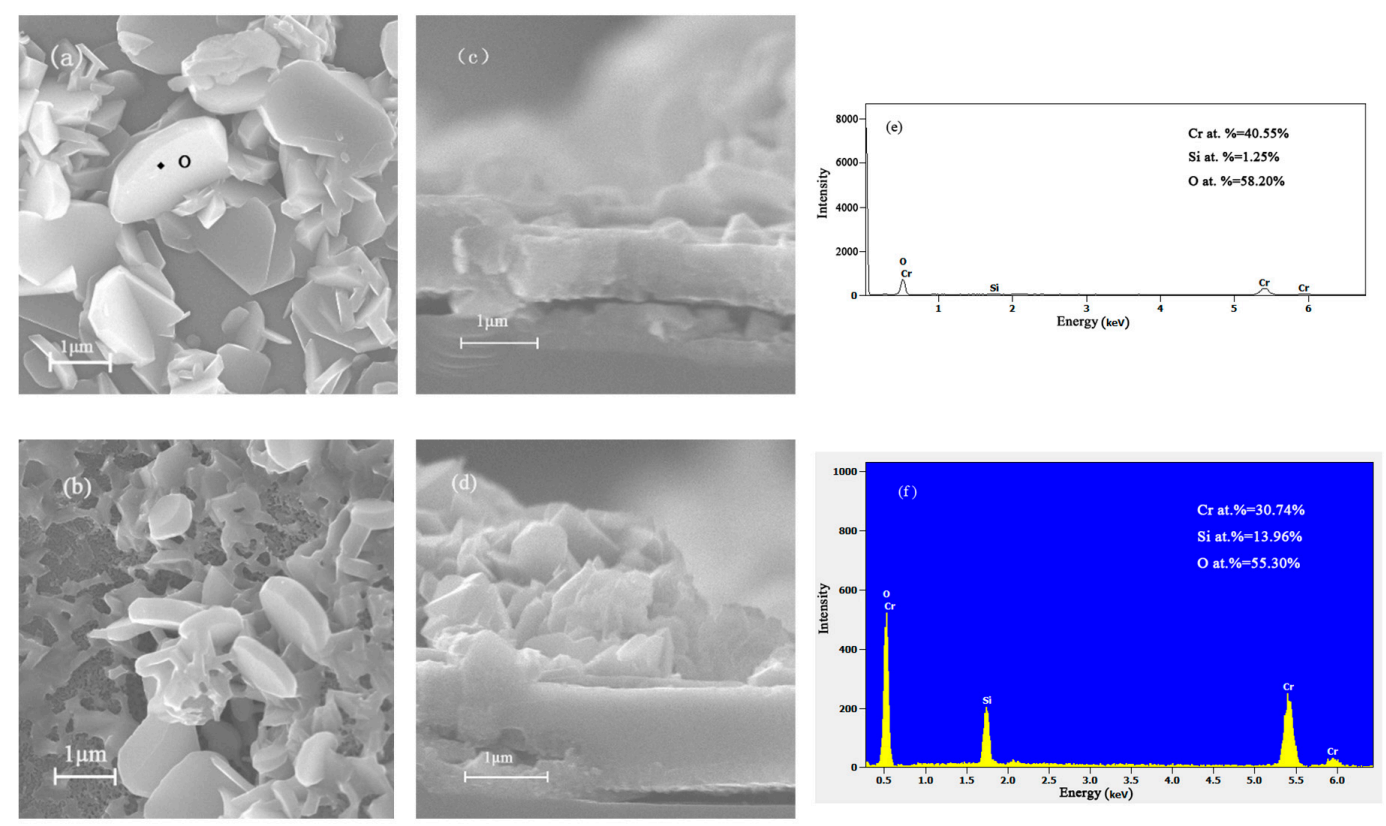

Figure 8. The SEM images of $\mathrm{Cr}-\mathrm{Si}-\mathrm{O}-\mathrm{N}$ coatings after annealing in the air for $2 \mathrm{~h}$ and EDS spectra: $(\mathbf{a}, \mathbf{c}) \mathrm{O}_{2} /\left(\mathrm{N}_{2}+\mathrm{O}_{2}\right)=2 \%, 1100{ }^{\circ} \mathrm{C} ;(\mathbf{b}, \mathbf{d}) \mathrm{O}_{2} /\left(\mathrm{N}_{2}+\mathrm{O}_{2}\right)=10 \%, 1100{ }^{\circ} \mathrm{C} ;(\mathbf{e})$ The EDS spectrum at point "O" in Figure 8a; (f) The EDS spectrum of Figure 8 b. 
Table 2. The cross-sectional chemical composition of the coatings after annealing at $800{ }^{\circ} \mathrm{C}, 1100{ }^{\circ} \mathrm{C}$, $1200{ }^{\circ} \mathrm{C}$.

\begin{tabular}{ccccccc}
\hline \multirow{2}{*}{ Samples } & \multicolumn{3}{c}{$\mathbf{C r}-\mathbf{S i - O}-\mathbf{N} \mathbf{( 2 \% )}$} & \multicolumn{3}{c}{$\mathbf{C r}-\mathbf{S i}-\mathbf{O}-\mathbf{N} \mathbf{( 1 0 \% )}$} \\
\cline { 2 - 7 } & $\mathbf{8 0 0}{ }^{\circ} \mathbf{C}$ & $\mathbf{1 1 0 0}{ }^{\circ} \mathbf{C}$ & $\mathbf{1 2 0 0}{ }^{\circ} \mathbf{C}$ & $\mathbf{8 0 0}^{\circ} \mathbf{C}$ & $\mathbf{1 1 0 0}{ }^{\circ} \mathbf{C}$ & $\mathbf{1 2 0 0}^{\circ} \mathbf{C}$ \\
\hline $\mathrm{Cr}$ & $39.05 \%$ & $29.70 \%$ & $25.92 \%$ & $34.45 \%$ & $25.01 \%$ & $22.47 \%$ \\
$\mathrm{Si}$ & $9.31 \%$ & $14.05 \%$ & $18.81 \%$ & $13.49 \%$ & $17.23 \%$ & $19.10 \%$ \\
$\mathrm{O}$ & $43.10 \%$ & $54.3 \%$ & $53.84 \%$ & $47.08 \%$ & $56.52 \%$ & $57.33 \%$ \\
$\mathrm{~N}$ & $8.54 \%$ & $1.86 \%$ & $1.43 \%$ & $4.98 \%$ & $1.24 \%$ & $1.10 \%$ \\
\hline
\end{tabular}

The electrochemical behavior of corrosion resistance of the deposited $\mathrm{Cr}-\mathrm{Si}-\mathrm{O}-\mathrm{N}$ films and cemented carbide substrate was tested by Electrochemical Working Station (CS350) in 3.5\% NaCl solution under free air condition at room temperature. The Tafel plots of the base cemented carbide substrate and $\mathrm{Cr}-\mathrm{Si}-\mathrm{O}-\mathrm{N}$ coatings with different oxygen contents are shown in Figure 9. The results such as corrosion potential, corrosion current, and polarization resistance fitted from the Tafel plots are listed in Table 3. It can be found that the corrosion potential $\left(E_{\text {corr }}\right)$ of uncoated cemented carbide substrate is about $-0.4650 \mathrm{~V}$ and the $E_{\text {corr }}$ of the coated samples shows a shift towards cathodic side compared to the substrate. Moreover, the corrosion current $\left(I_{\text {corr }}\right)$ is decreased while the polarization resistance $\left(R_{\mathrm{p}}\right)$ is increased with the oxygen content increasing, which indicates the better corrosion resistance of the coated samples. However, the $\mathrm{Cr}-\mathrm{Si}-\mathrm{N}$ coatings have better corrosion rate than that of the $\mathrm{Cr}-\mathrm{Si}-\mathrm{O}-\mathrm{N}$ coatings. The Nyquist plots can also be used to evaluate the corrosion resistance performance of the coatings, and the results are shown in Figure 10.

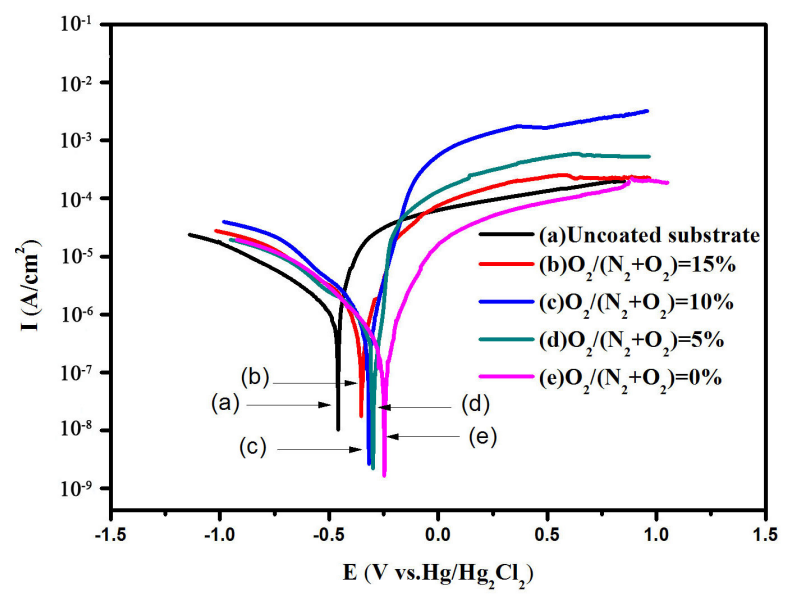

Figure 9. Potentiodynamic polarization curves of bare steel substrate and $\mathrm{Cr}-\mathrm{Si}-\mathrm{O}-\mathrm{N}$ coatings with difference $\mathrm{O}_{2} /\left(\mathrm{N}_{2}+\mathrm{O}_{2}\right)$ flux rate.

Table 3. Corrosion potential, corrosion current, polarization resistance and corrosion rate properties got from the Tafel plots.

\begin{tabular}{ccccc}
\hline Samples & $\boldsymbol{E}_{\text {corr }}(\mathbf{V})$ & $\boldsymbol{I}_{\text {corr }}\left(\boldsymbol{\mu} \mathbf{A} / \mathbf{c m}^{\mathbf{2}}\right)$ & $\boldsymbol{R}_{\mathbf{p}}\left(\mathbf{k} \boldsymbol{\Omega} \cdot \mathbf{c m}^{\mathbf{2}}\right)$ & $\boldsymbol{C}_{\text {orr rate }}(\mathbf{m m} / \mathbf{A})$ \\
\hline Substrate & -0.4650 & 2.65 & 14.95 & $13.46 \times 10^{-3}$ \\
Cr-Si-N & -0.2541 & 0.35 & 123.39 & $4.02 \times 10^{-3}$ \\
Cr-Si-O-N $(5 \%)$ & -0.2645 & 0.41 & 98.63 & $5.94 \times 10^{-3}$ \\
Cr-Si-O-N $(10 \%)$ & -0.3099 & 0.72 & 49.92 & $6.25 \times 10^{-3}$ \\
Cr-Si-O-N $(15 \%)$ & -0.3489 & 0.96 & 49.69 & $7.01 \times 10^{-3}$ \\
\hline
\end{tabular}




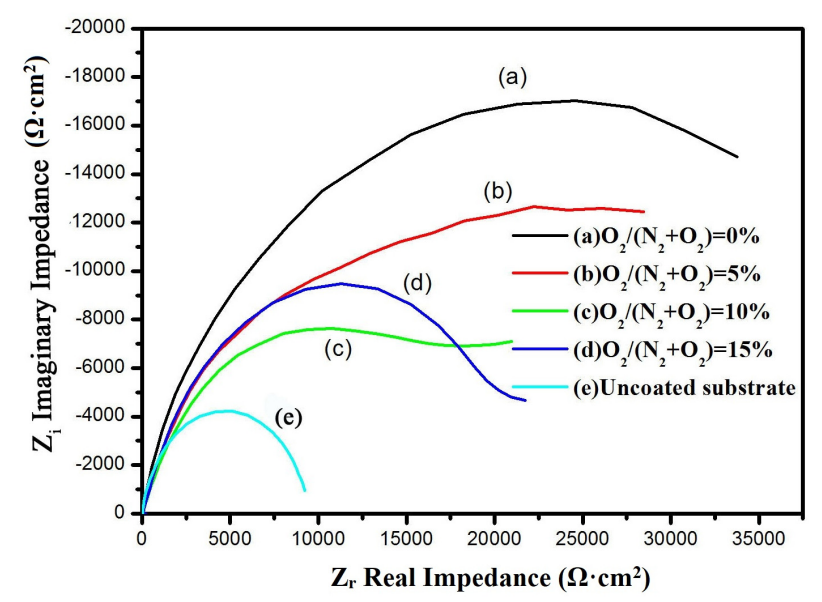

Figure 10. Nyquist plots of bare steel substrate and $\mathrm{Cr}-\mathrm{Si}-\mathrm{O}-\mathrm{N}$ coatings with difference $\mathrm{O}_{2} /\left(\mathrm{N}_{2}+\mathrm{O}_{2}\right)$ flux rate.

The equivalent circuit for substrate is shown in Figure 11A, and the proposed equivalent circuit for $\mathrm{Cr}-\mathrm{Si}-\mathrm{O}-\mathrm{N}$ coatings on the WC-Co cemented carbide substrate with defects (large particles and pinholes) is shown in Figure 11B [24]. Here, $R_{\mathrm{S}}$ is the solution resistance, $\mathrm{CPE}_{\mathrm{C}}$ represents the constant phase element related to the coatings, $\mathrm{CPE}_{\mathrm{dl}}$ represents the constant phase element of the electrical double layer, WE is the working electrode, and $R_{\mathrm{C}}$ is the coating resistance [25]. Table 4 shows the fitting results of the equivalent electrical circuit of Figure 11. The fit errors of the values presented in the table are less than $10 \%$. From the table, it can be seen that the $R_{\mathrm{ct}}$ which is the charge transfer resistance decreased from 50.15 to $23.48 \mathrm{k} \Omega \cdot \mathrm{cm}^{2}$ with the increasing of oxygen contents, which also provides the evidence that the $\mathrm{Cr}-\mathrm{Si}-\mathrm{N}$ coatings have better corrosion resistance than that of $\mathrm{Cr}-\mathrm{Si}-\mathrm{O}-\mathrm{N}$ coatings.
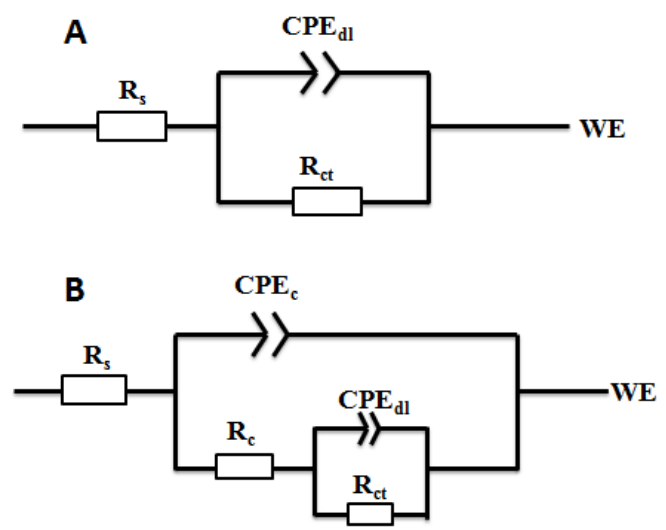

Figure 11. (A) Equivalent circuit to fit the electrochemical impedance data of the WC-Co cemented carbide substrate; (B) General Equivalent circuit to fit the electrochemical impedance data of the coated samples.

Table 4. Fitting results of EIS plots in Figure 11.

\begin{tabular}{|c|c|c|c|c|c|}
\hline Samples & $R_{\mathrm{S}}\left(\Omega \cdot \mathrm{cm}^{2}\right)$ & $\mathrm{CPE}_{\mathrm{c}}-Y_{0}\left(\mu \mathrm{F} \cdot \mathrm{cm}^{2}\right)$ & $R_{\mathrm{c}}\left(\Omega \cdot \mathrm{cm}^{2}\right)$ & $\mathrm{CPE}_{\mathrm{dl}}-Y_{0}\left(\mu \mathrm{F} \cdot \mathrm{cm}^{2}\right)$ & $R_{\mathrm{ct}}\left(\mathrm{k} \Omega \cdot \mathrm{cm}^{2}\right)$ \\
\hline Substrate & 19.11 & - & - & 95.55 & 9.46 \\
\hline $\mathrm{Cr}-\mathrm{Si}-\mathrm{N}$ & 19.91 & 25.60 & 2573 & 52.34 & 50.15 \\
\hline Cr-Si-O-N (5\%) & 20.23 & 85.61 & 1970 & 46.39 & 30.15 \\
\hline $\mathrm{Cr}-\mathrm{Si}-\mathrm{O}-\mathrm{N}(10 \%)$ & 22.60 & 89.83 & 1898 & 62.33 & 22.57 \\
\hline $\mathrm{Cr}-\mathrm{Si}-\mathrm{O}-\mathrm{N}(15 \%)$ & 20.82 & 87.62 & 1851 & 53.01 & 23.48 \\
\hline
\end{tabular}




\section{Conclusions}

$\mathrm{Cr}-\mathrm{Si}-\mathrm{O}-\mathrm{N}$ coatings with different oxygen contents were deposited by multi-arc ion plating. The oxygen contents of the deposited coatings significantly increased from 0 to 40 at. $\%$ and the $\mathrm{N}$ contents sharply decreased from 31.5 to 5 at. $\%$ when the $\mathrm{O}_{2} /\left(\mathrm{N}_{2}+\mathrm{O}_{2}\right)$ flux rate increased from $0 \%$ to $10 \%$. With the addition of oxygen, the diffraction peaks of $\mathrm{CrN}$ (111) and $\mathrm{CrN}$ (200) became weaker and the diffraction peaks of $\mathrm{CrN}$ phases were no longer recognizable when the $\mathrm{O}_{2} /\left(\mathrm{N}_{2}+\mathrm{O}_{2}\right)$ flux rate above $10 \%$. The Cr-Si-O-N coatings remained stable after annealed at $800{ }^{\circ} \mathrm{C}$ in the air for $2 \mathrm{~h}$ but break appeared in the inner structure after annealing at $1200^{\circ} \mathrm{C}$. The XRD, SEM and electrochemical corrosion resistance results showed that the $\mathrm{Cr}-\mathrm{Si}-\mathrm{N}$ coatings have better oxidation and corrosion resistance properties than that of $\mathrm{Cr}-\mathrm{Si}-\mathrm{O}-\mathrm{N}$ coatings with various oxygen contents.

Acknowledgments: This work was supported by the Natural Science Foundation of Guangdong Province (No. 2014A030307008, 2016A030313670), Project for training high-level talents of "Yangfan Plan" in Guangdong Province, Innovation project of universities in Guangdong Province (2015KTSCX086) and Natural Science Foundation of Lingnan Normal University (LZL1506, QL1512, and ZL1503).

Author Contributions: Jinjue Liang and Changwei Zou conceived and designed the experiments; Jinjue Liang and Shimin Chen performed the experiments; Jinjue Liang; Zesong Wang; Canxin Tian; Changwei Zou and Shijun Liao and analyzed the data; Jinjue Liang and Changwei Zou wrote the paper.

Conflicts of Interest: The authors declare no conflict of interest.

\section{References}

1. Creus, J.; Idrissi, H.; Mazille, H.; Sanchette, F.; Jacquot, P. Improvement of the corrosion resistance of CrN coated steel by an interlayer. Surf. Coat. Technol. 1998, 107, 183-190. [CrossRef]

2. Mercs, D.; Bonasso, N.; Naamane, S.; Bordes, J.-M.; Coddet, C. Mechanical and tribological properties of Cr-N and Cr-SI-N coatings reactively sputter deposited. Surf. Coat. Technol. 2005, 200, 403-407. [CrossRef]

3. Chen, H.-Y.; Lu, F.-H. Oxidation behavior of chromium nitride films. Thin Solid Films 2006, 515, $2179-2184$. [CrossRef]

4. Navinšek, B.; Panjan, P.; Milošev, I. Industrial applications of CrN (PVD) coatings, deposited at high and low temperatures. Surf. Coat. Technol. 1997, 97, 182-191. [CrossRef]

5. Veprek, S.; Veprek-Heijman, M.G.J.; Karvankova, P.; Prochazka, J. Different approaches to superhard coatings and nanocomposites. Thin Solid Films 2005, 476, 1-29. [CrossRef]

6. Veprek, S.; Mannling, H.D.; Niederhofer, A.; Ma, D.; Mukherjee, S. Degradation of superhard nanocomposites by built-in impurities. J. Vac. Sci. Technol. 2004, 22, L5-L9. [CrossRef]

7. Veprek, S.; Veprek-Heijman, M.G.J. Limits to the preparation of superhard nanocomposites: Impurities, deposition and annealing temperature. Thin Solid Films 2012, 522, 274-282. [CrossRef]

8. Veprek, S.; Mannling, H.D.; Karvankova, P.; Prochazka, J. The issue of the reproducibility of deposition of superhard nanocomposites with hardness of $\geq 50$ GPa. Surf. Coat. Technol. 2004, 200, 3876-3885. [CrossRef]

9. Camps, I.; Muhl, S.; Camps, E.; Quinones-Galvan, J.G.; Flores, M. Tribological properties of TiSiN thin films deposited by laser ablation. Surf. Coat. Technol. 2014, 255, 74-78. [CrossRef]

10. Xu, Y.; Chen, L.; Liu, Z.; Pei, F.; Du, Y. Improving thermal stability of TiSiN nanocomposite coatings by multilayered epitaxial growth. Surf. Coat. Technol. 2017, 321, 180-185. [CrossRef]

11. Yao, Y.; Li, J.; Wang, Y.; Ye, Y.; Zhu, L. Influence of the negative bias in ion plating on the microstructural and tribological performances of Ti-Si-N coatings in seawater. Surf. Coat. Technol. 2015, 280, 154-162. [CrossRef]

12. Ma, D.; Ma, S.; Xu, K.; Veprek, S. Effecting of oxygen and chlorine on nano-structured TiN/Si ${ }_{3} \mathrm{~N}_{4}$ films hardness. Mater. Lett. 2005, 59, 838-841.

13. Lee, J.D.; Wang, Q.M.; Kim, S.-H.; Wang, T.-G.; Shin, D.-W.; Kim, K.H. Microstructure and mechanical properties of quaternary $\mathrm{Cr}-\mathrm{Si}-\mathrm{O}-\mathrm{N}$ films by a hybrid coating system. Surf. Coat. Technol. 2012, 206, 3721-3727. [CrossRef]

14. Wang, Q.; Kim, K.H. Microstructural control of Cr-Si-N films by a hybrid arc ion plating and magnetron sputtering process. Acta Mater. 2009, 57, 4974-4987. [CrossRef]

15. Khatibi, A.; Sjolen, J.; Greczynski, G.; Jensen, J.; Eklund, P.; Hultman, L. Structural and mechanical properties of Cr-Al-O-N thin films grown by cathodic arc deposition. Acta Mater. 2012, 60, 6494-6507. [CrossRef] 
16. Lee, H.Y.; Jung, W.S.; Han, J.G.; Seo, S.M.; Kim, J.H.; Bae, Y.H. The synthesis of CrSiN film deposited using magnetron sputtering system. Surf. Coat. Technol. 2005, 200, 1026-1030. [CrossRef]

17. Ingo, G.M.; Zacchetti, N. XPS investigation on the growth model of a-SiNx and silicon and nitrogen chemical bondings. High Temp. Sci. 1988, 28, 137-151.

18. Wang, L.; Zhang, S.; Chen, Z.; Li, J.; Li, M. Influence of deposition parameters on hard Cr-Al-N coatings deposited by multi-arc ion plating. Appl. Surf. Sci. 2012, 258, 3629-3636. [CrossRef]

19. Vepřek, S. Conventional and new approaches towards the design of novel superhard materials. Surf. Coat. Technol. 1997, 97, 15-22. [CrossRef]

20. Dong, B.L.; Nguyen, T.D.; Sun, K.K. Air-oxidation of nano-multilayered CrAlSiN thin films between 800 and $1000{ }^{\circ}$ C. J. Nanosci. Nanothchno. 2009, 203, 1199-1204.

21. Kim, J.W.; Kim, K.H.; Lee, D.B.; Moore, J.J. Study on high-temperature oxidation behaviors of Cr-Si-N films. Surf. Coat. Technol. 2006, 200, 6702-6705. [CrossRef]

22. Pshyk, A.V.; Coy, L.E.; Nowaczyk, G.; Kempiński, M.; Peplińska, B.; Pogrebnjak, A.D.; Beresnev, V.M.; Jurga, S. High temperature behavior of functional TiAlBSiN nanocomposite coatings. Surf. Coat. Technol. 2016, 305, 49-60. [CrossRef]

23. Saladukhin, I.A.; Abadias, G.; Uglov, V.V.; Zlotski, S.V.; Michel, A.; van Vuuren, A.J. Thermal stability and oxidation resistance of $\mathrm{ZrSiN}$ nanocomposite and $\mathrm{ZrN} / \mathrm{SiNx}$ multilayered coatings: A comparative study. Surf. Coat. Technol. 2017, 332, 428-439. [CrossRef]

24. Grips, V.K.W.; Barshilia, H.C.; Ezhil Selvi, V.; Kalavati; Rajam, K.S. Electrochemical behavior of single layer $\mathrm{CrN}$, TiN, TiAlN coatings and nanolayered TiAlN/CrN multilayer coatings prepared by reactive direct current magnetron sputtering. Thin Solid Films 2006, 514, 204-211.

25. Zhang, L.J.; Mohammed, E.A.A.; Adriaens, A. Synthesis and electrochemical behavior of a magnesium fluoride-polydopamine-stearic acid composite coating on AZ31 magnesium alloy. Surf. Coat. Technol. 2016, 307, 56-64. [CrossRef]

(C) 2018 by the authors. Licensee MDPI, Basel, Switzerland. This article is an open access article distributed under the terms and conditions of the Creative Commons Attribution (CC BY) license (http:/ / creativecommons.org/licenses/by/4.0/). 